\title{
A Multi-Criteria Vertical Coordination Framework for a Reliable Aid Distribution
}

\author{
Fabiola Regis-Hernández ${ }^{1}$ (D) Jaime Mora-Vargas ${ }^{1}$ (D), Angel Ruíz ${ }^{2}$ (DD \\ ${ }^{1}$ Tecnológico de Monterrey (Mexico) \\ ${ }^{2}$ Centre interuniversitaire de recherche sur les réseaux d'entreprise, la logistique et le transport (CIRRELT), Faculty of \\ Business Administration, Université Laval, Quebec (Canada)
}

fregisher@.gmail.com,_mora@itesm.mx,.Angel.rui_@_fsa.ulaval.ca

Received: February 2017

Accepted: September 2017

\section{Abstract:}

Purpose: This study proposes a methodology that translates multiple humanitarian supply chain stakeholders' preferences from qualitative to quantitative values, enabling these preferences to be integrated into optimization models to ensure their balanced and simultaneous implementation during the decision-making process.

Design/methodology/approach: An extensive literature review is used to justify the importance of developing a strategy that minimizes the impact of a lack of coordination on humanitarian logistics decisions. A methodology for a multi-criteria framework is presented that allows humanitarian stakeholders' interests to be integrated into the humanitarian decisionmaking process.

Findings: The findings suggest that integrating stakeholders' interests into the humanitarian decision-making process will improve its reliability. 
Research limitations/implications: To further validate the weights of each stakeholder's interests obtained from the literature review requires interviews with the corresponding organizations. However, the literature review supports the statements in this paper.

Practical implications: The cost of a lack of coordination between stakeholders in humanitarian logistics has been increasing during the last decade. These coordination costs can be minimized if humanitarian logistics' decision-makers measure and simultaneously consider multiple stakeholders' preferences.

Social implications: When stakeholders' goals are aligned, the humanitarian logistics response becomes more efficient, increasing the quality of delivered aid and providing timely assistance to the affected population in order to minimize their suffering.

Originality/value: This study provides a methodology that translates humanitarian supply chain stakeholders' interests into quantitative values, enabling them to be integrated into mathematical models to ensure relief distribution based on the stakeholders' preferences.

Keywords: humanitarian logistics, relief distribution, stakeholders, response, methodology, vertical coordination, multi-criteria

\section{Introduction}

Humanitarian logistics represents the activities performed before, during, and after a disaster in order to diminish its impact. The main task of humanitarian logistics is delivering appropriate supplies in good condition and in the required amounts to the right places at the right moment (Ortuño, Cristóbal, Ferrer, Martín-Campo, Muñoz, Tirado et al., 2013).

Disasters are divided into four life-cycle stages, as presented in Altay and Green (2006) (Figure 1). "Mitigation" and "preparedness," better known as the pre-disaster stages, take place before the disaster occurs in order to minimize its occurrence probability or, in the worst case, its negative effects. In these stages, protocols are reinforced, and people are trained to be prepared for a new disaster. Then, the post-disaster stages are "response" and "recovery," which try to minimize the effects of a disaster by helping people as quickly as possible, and by supporting the community in returning their lives to how they were prior to the disaster (Altay \& Green, 2006; Ang \& Hern, 2015). 
The response life-cycle stage requires the intervention of international and local actors, largely owing to its characteristics (e.g., the increase in demand urgency and volume) (Ang \& Hern, 2015). The uncertainty of demand, resource scarcity, and competition for funds are already challenges in relief distribution. However, the number and diversity of actors involved in the process directly impact the efficiency of the humanitarian supply chain (Balcik, Beamon, Krejci, Muramatsu \& Ramirez, 2010), making coordination among these actors a key aspect.

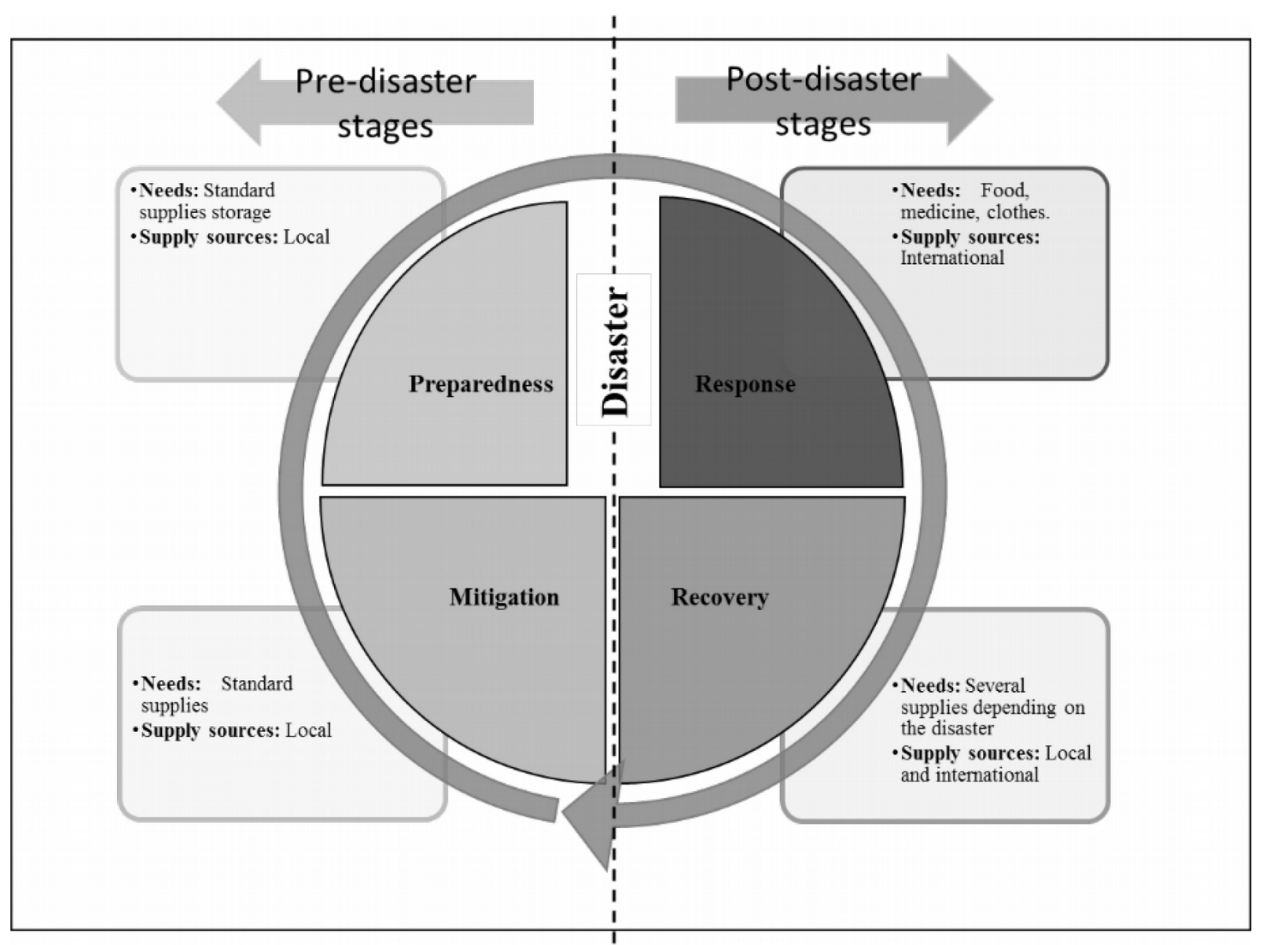

Figure 1. Disaster life cycle stages (Altay \& Green, 2006)

The mandatory intervention of several stakeholders, each with their own goals, interests, capacities, and expertise, means a lack of coordination among them results in ineffective relief distribution. This can cause, for example, resources to be used in an inadequate manner, and relief efforts to be duplicated (Moshtari \& Gonçalves, 2011).

Coordination can be represented in a horizontal or a vertical manner. Horizontal coordination refers to the relations among competitors and/or non-competitors who provide similar services, or among internal departments with similar functions (Akhtar, Marr \& Garnevsca, 2012). Vertical coordination refers to the parallel actions of suppliers and customers, or across departments within the same organization. This type of coordination can be found in upstream or downstream activities (Balcik et al., 2010; Moshtari \& Gonçalves, 2011). 
To solve the relief distribution problem, several optimization models have been proposed, each tackling the problem from a different perspective and, in most cases, resulting in multi-objective models. The pursuit of more than one objective and the intervention of several actors (horizontal and vertical coordination) requires using multi-criteria decision-making methods to achieve a balanced and effective solution to realize the goals of the humanitarian supply chain. In addition, there is increased interest in developing metrics to evaluate humanitarian supply chain performance. To integrate these metrics into the decision-making process, and to combine them with stakeholders' preferences, we need to translate these preferences into quantified values in order to make effective and efficient decisions.

This work presents and applies a methodology as a strategy to solve the problem of a lack of coordination in the humanitarian supply chain. The remainder of the paper is organized into four sections. Section 1 introduces the problem and states the goals of the research. Section 2 reviews the literature on coordinating the humanitarian supply chain. Section 3 describes the proposed methodology for developing a multi-criteria framework. Lastly, Section 4 concludes the paper, and suggests possible areas for future research.

\section{Literature Review}

In order to provide a context for this research, this section reviews existing literature related to coordinating humanitarian logistics. This section establishes the importance of this study. The contributions presented in this section were identified through a detailed search of the ISI Web of Knowledge and Scopus. The keywords used in the search were coordination, disaster, humanitarian, relief, response, distribution, and supply chain.

Many studies have examined coordination in the context of commercial supply chains, but few have done so in the context of their humanitarian counterparts. Several authors have focused on understanding coordination itself, and the challenges resulting from a lack thereof in humanitarian supply chains. Furthermore, the number of studies related to the development of qualitative and quantitative strategies to overcome these challenges has increased in the last five years.

In order to make this research as complete as possible and given the limited number of contributions related to the response in the aftermath of natural disasters, a systematic review methodology was used as follows: 
1. Identification of the investigation. With this literature review, we intend to find as many as possible contributions related to the coordination problem in the humanitarian logistics context, specifically in the relief distribution during the response phase.

2. Material collection. In order to do this research, a query considering the keywords "coordination", "disaster", "humanitarian", "relief”, and "response", was submitted to ISI Web of Knowledge and Scopus databases. The keywords were explored in titles and abstracts.

3. Inclusion and exclusion criteria

a) Inclusion criteria. The literature review considered analytical and empirical academic publications such as peer-reviewed papers, conference proceedings with full-paper, and dissertations due to their academic relevance. All the references included in this literature review meet the characteristics presented in the identification of research point. Also, the references are aligned with the Operational Research, Transportation, and Industrial Engineering categories. Due to the lack of contributions related to the coordination problem in humanitarian logistics, the date range was established between 1996 and 2017, justified by the fact that most of the contributions related to humanitarian logistics are presented within this period. Considering the limited number of contributions, books' chapters and the governmental and military reports were included in this research.

b) Exclusion criteria. Non-English articles and manuals were excluded from the analysis.

After this search, a total of 384 documents were found in the databases. With a second filter, duplicates were eliminated and the sample was reviewed to ensure that the remaining papers meet the inclusion and exclusion criteria. As the articles were reviewed the inclusion of other pertinent cited articles was carried out. Finally, a total of 27 papers met the inclusion and exclusion criteria.

Following, some of the most important contributions related to coordination in humanitarian logistics are presented. Due to the recent concern about to deal with the lack of coordination among stakeholders in the humanitarian logistics, must of the contributions remains in a qualitative context.

In 2010, Balcik et al. (2010), presented an overview of the coordination issues related to relief chains, and concluded that coordination is one of the critical aspects of the humanitarian supply chain that must be improved in order to increase its efficiency. Then, the behavior, drivers, and barriers related to the horizontal coordination of organizations in the humanitarian supply chain are presented in Moshtari and Gonçalves (2011). Dolinskaya, Shi and Smilowitz (2011), identify that the large number and diversity of actors, urgency of a humanitarian relief response, short period in which to establish coordination, limited information sharing and communication, allocation of costs, risk, and insufficient 
personnel dedicated to logistics coordination are the main challenges to improving the coordination among humanitarian stakeholders. Strategies to overcome these challenges are also presented in the latter work, but they focus on a qualitative aspect. Another example of qualitative research is that of Hovhanessian (2012), who uses interviews and a literature review to analyze the vertical coordination barriers that exist between humanitarian organizations and commercial agencies in relief distribution. In addition, Heaslip (2012) contributes to the literature with an empirical comparison of military and humanitarian organizations, proposing a framework that identifies the interactions between stakeholders and involved components.

In addition to these qualitative studies, Huang, Li and Omitaomu (2011) propose a conceptual mathematical model to evaluate the coordination within the humanitarian supply chain, taking into account the overall coordination costs of procurement, and warehousing and transportation activities (pre- and post- disaster stages). Kabra, Ramesh and Arshinder (2015) present a pioneering attempt to prioritize barriers to coordination. They identify, classify, verify, and prioritize the coordination barriers, specifically for the Indian context. Their study concludes that management and technological barriers have the greatest impact on coordination. Finally, Gralla, Goentzel and Fine (2014), using a conjoint analysis, evaluate and develop an objective function to represent the goals of humanitarian relief. These authors used a group of humanitarian logisticians (horizontal coordination) to value the trade-offs among the multiple humanitarian aid goals.

Based on the literature review, we conclude that researchers attach great importance to the lack coordination among humanitarian supply chain stakeholders. Many studies quantify the impact of a lack of coordination on supply chains, but recently, there has been growing interest in translating humanitarian supply chain stakeholders' preferences from qualitative into quantitative values, thus, making it possible to integrate them into the decision-making process.

\section{Multi-Criteria Framework Development Methodology}

The intervention of several stakeholders in the aftermath of a disaster is unavoidable, and a lack of coordination between them can cause a lack of efficiency and duplicated efforts. Humanitarian logistics experts must make decisions under uncertainty and within a short time, but must also consider multiple stakeholders' preferences during the decision-making process. This becomes a challenge, owing to the complexity of decisions problems that involve ranking, choice, and sorting. Often, a perfect solution that satisfies all stakeholder preferences is not possible. However, it is possible to identify a good solution that satisfies most stakeholder preferences. 
In this section, based on the literature review, we present the proposed methodology that translates the humanitarian supply chain stakeholders' preferences from qualitative into quantitative values. As such, these preferences can be integrated into the decision-making process. After prioritizing stakeholders' interests, these are integrated into a multi-criteria objective function used to evaluate the distribution of relief.

To achieve our goal, we consider a general relief distribution scenario during the response stage. Once a disaster occurs, vertical coordination is used to coordinate the intervention of governmental and non-governmental organizations, donors, the private sector, and military organizations to attend to the affected population.

In order to identify, prioritize, and translate the preferred objectives in the humanitarian supply chain from qualitative to quantitative values, we propose the methodology shown in Figure 2 to develop a multi-criteria framework.

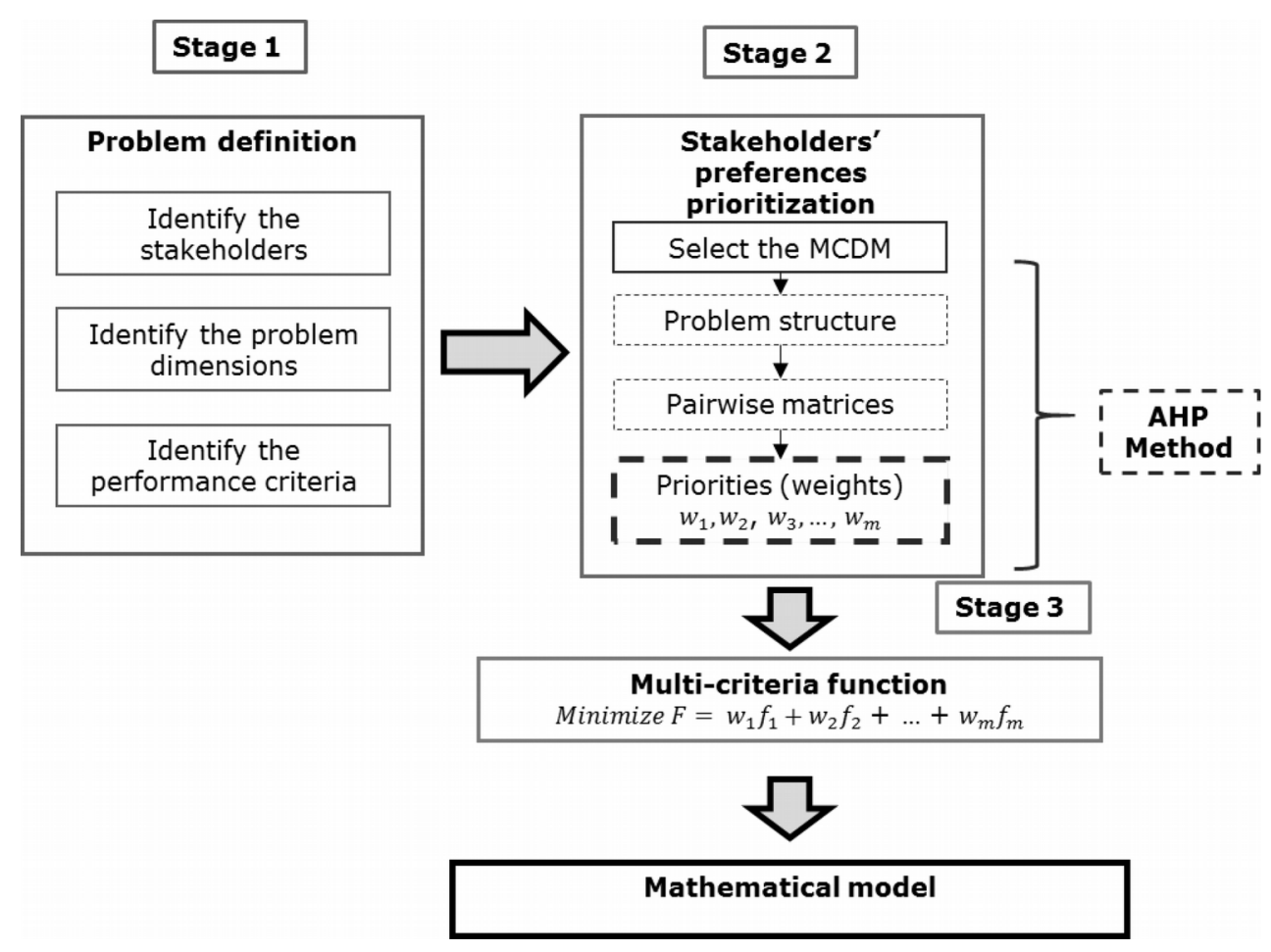

Figure 2. Methodology

The methodology comprises three main stages: defining the problem; selecting and applying a multi-criteria decision-making ( $\mathrm{MCDM}$ ) method to translate the stakeholders' interests into 
quantitative values; and formulating the multi-criteria function, enabling it to be solved using mathematical programming.

\subsection{Problem Definition (Stage 1)}

This stage aims to identify the (1) stakeholders, (2) problem dimensions, and (3) performance criteria.

\subsubsection{Stakeholders}

As stated earlier, for the purpose of this work, we use vertical coordination (see Figure 3). Here, in a hierarchy, governmental organizations are identified as Level 1, non-governmental organizations as Level 2, and donors, private sector companies, and military organizations as Level 3. The stakeholder profiles are determined by identifying their responsibilities (Table 1) and their goals (Table 2).

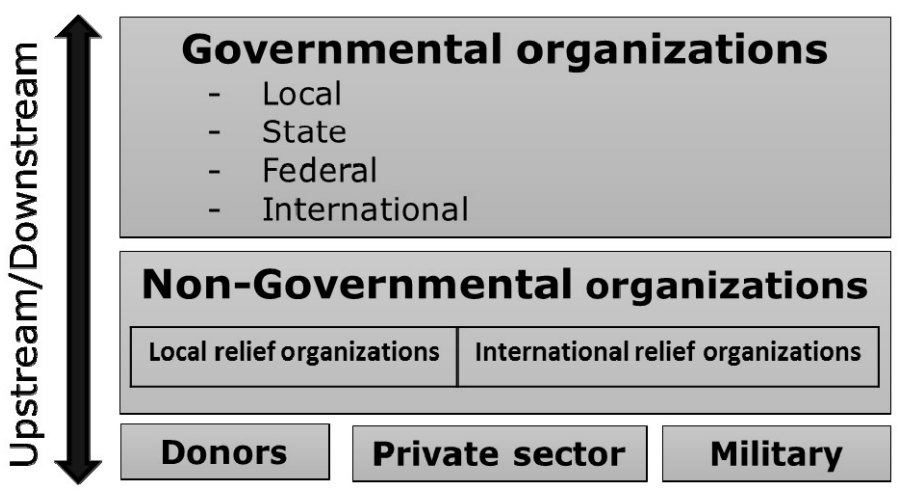

Figure 3. Vertical coordination (Balcik et al., 2010; Moshtari \& Gonçalves, 2011)

\begin{tabular}{|l|l|}
\hline \multicolumn{1}{|c|}{ Vertical coordination level } & \multicolumn{1}{c|}{ Responsibilities } \\
\hline Governmental organizations & The coordination of actors involved in the relief distribution process. \\
\hline Non-governmental organizations & Relief distribution (food, water, and medical supplies). \\
\hline Private sector companies/Donors & $\begin{array}{l}\text { Provide financial or in-kind donations, and share transportation resources } \\
\text { (physical or/and knowledge). }\end{array}$ \\
\hline Military & Provide security, logistics skills, repair, communications, and medical care. \\
\hline
\end{tabular}

Table 1. Vertical coordination stakeholders' responsibilities (Balcik et al., 2010) 


\begin{tabular}{|l|l|}
\hline \multicolumn{1}{|c|}{ Vertical coordination level } & \multicolumn{1}{c|}{ Goals } \\
\hline Governmental organizations & To minimize the costs related to the lack of coordination among organizations. \\
\hline Non-governmental organizations & $\begin{array}{l}\text { To manage resources in order to maximize the coverage and equity of the } \\
\text { demand. }\end{array}$ \\
\hline Private sector companies / Donors & To increase the efficiency of the humanitarian supply chain. \\
\hline Military & $\begin{array}{l}\text { To maximize the reliability of the aid delivery process (planned vs real, } \\
\text { considering the complications linked to the relief distribution problem), but also } \\
\text { to minimize the relief response time. }\end{array}$ \\
\hline
\end{tabular}

Table 2. Vertical coordination to address stakeholders' goals

\subsubsection{Problem Dimensions}

The dimensions of the problem are the aspects to be evaluated. Based on the literature review presented in Table 3, the most used objective functions can be classified into three dimensions (social, reliable, and economic). The social dimension refers to the impact on the affected population of a lack of access to a good or service. The reliability dimension aims to meet the demand as planned, considering most of the cases, the response/travel time linked to the damaged infrastructure, and the possibility of second, third, or more disasters occurring during the relief distribution. Finally, in the economic dimension, although minimizing costs (financial, human, technical, and material) is not the main objective, when NGO decision-makers define where and how aid will be delivered and the resources required to do so, minimizing relevant costs is one of the metrics used to evaluate a supply chain and stakeholders' interests. This measure usually evaluates how the inputs are converted into outputs (e.g., the number of vehicles required, and the travel distance or travel time).

\subsubsection{Performance Criteria}

The concept of performance criteria refers to how the dimensions (economic, social, and reliable) are measured. To determine the performance criteria for this framework, an extensive literature review was performed.

To make this research as complete as possible, a query containing the keywords "disaster", "humanitarian", "relief", "mathematical programming", and "distribution", was submitted to ISI Web and Scopus databases. As inclusion criteria, the literature review considered analytical and empirical academic publications such as peer-reviewed papers, conference proceedings with full-paper, books, and dissertations. To restrict more our research, the search was limited to the contributions within the Operational Research, Transportation, and Industrial Engineering categories. The data range was 
established between 1996 and 2016. Additionally, to reflect our interest in the response stage, the selected contributions were focused on this phase. The research was limited to the network design and transportation, justified by the fact those are the main activities during the relief distribution and are the ones analyzed in this paper. Furthermore, given a large number of contributions in the response stage context, we limited our search to papers tackling sudden-onset disasters only. The manuals and governmental or military reports were excluded from this research. Articles solely focused on pre-positioning and warehousing were also excluded. The contributions only consider those written in English. Finally, after a debug of the initial 1040 documents, a total of 59 papers that meet the inclusion and exclusion criteria were found (see Table 3).

\begin{tabular}{|c|c|c|c|c|c|c|c|c|c|c|}
\hline Reference & MC & MTD & MPC & MV & MUD & MLAT & MESD & MRT & MTT & MTR \\
\hline Haghani and Oh (1996) & $\mathrm{X}$ & & & & & & & & & \\
\hline Oh and Haghani (1997) & $\mathrm{X}$ & & & & & & & $\mathrm{X}$ & & \\
\hline Barbarosoglu, Özdamar and Cevik (2002) & $\mathrm{X}$ & & & & & & & $\mathrm{x}$ & & \\
\hline Viswanath and Peeta (2003) & $\mathrm{X}$ & & & & & & & & & \\
\hline Barbarosoğlu and Arda (2004) & $\mathrm{X}$ & & & & & & & & & \\
\hline Özdamar, Ekinci and Küçükyazici (2004) & & & & & $\mathrm{x}$ & & & & & \\
\hline Tzeng, Cheng and Huang (2007) & $\mathrm{X}$ & & & & $\mathrm{x}$ & & & $\mathrm{X}$ & & \\
\hline Yi and Kumar (2007) & & & & & $\mathrm{x}$ & & & & & \\
\hline Yi and Özdamar (2007) & & & & & $\mathrm{x}$ & & & $\mathrm{X}$ & & \\
\hline de Angelis, Mecoli, Nikoi and Storchi (2007) & & & & & $\mathrm{x}$ & & & & & \\
\hline Horner and Downs (2007) & $\mathrm{X}$ & & & & & & & & & \\
\hline Jia, Ordo and Dessouky (2007) & & & & & $\mathrm{X}$ & & & & & \\
\hline Sheu (2007) & & & & & & & & $\mathrm{X}$ & & \\
\hline Balcik, Beamon and Smilowitz (2008) & $\mathrm{X}$ & & & & & & & & & \\
\hline Balcik and Beamon (2008) & & & & & $\mathrm{X}$ & & & & & \\
\hline Campbell, Vandenbussche and Hermann (2008) & $\mathrm{X}$ & & & & & $\mathrm{X}$ & & $\mathrm{X}$ & & \\
\hline Hsueh, Chen and Chou (2008) & & & & & & & & & $\mathrm{X}$ & \\
\hline Zografos and Androutsopoulos (2008) & $\mathrm{X}$ & & & & & & & & & $\mathrm{x}$ \\
\hline $\operatorname{Lin}(2009)$ & & & & & $\mathrm{x}$ & & & $\mathrm{X}$ & $\mathrm{X}$ & \\
\hline Vitoriano, Ortuño and Tirado (2009) & $\mathrm{X}$ & & & & & & & & & $\mathrm{x}$ \\
\hline Yuan and Wang (2009) & & & $\mathrm{X}$ & & & & & & $\mathrm{X}$ & \\
\hline Zhu and Ji (2009) & $\mathrm{X}$ & & & & $\mathrm{x}$ & & & & & \\
\hline Afshar and Haghani (2009) & & & & & $\mathrm{x}$ & & & & & \\
\hline Adivar and Mert (2010) & $\mathrm{X}$ & & & & & & & & & $\mathrm{x}$ \\
\hline Chern, Chen and Kung (2010) & & & & & & & & $\mathrm{X}$ & & $\mathrm{x}$ \\
\hline Campbell and Jones (2011) & $\mathrm{X}$ & & & & & & & & & \\
\hline Horner and Downs (2010) & $\mathrm{X}$ & & & & & & & & & \\
\hline Mete and Zabinsky (2010) & $\mathrm{X}$ & & & & $\mathrm{x}$ & & & & $\mathrm{X}$ & \\
\hline
\end{tabular}




\begin{tabular}{|c|c|c|c|c|c|c|c|c|c|c|}
\hline Reference & MC & MTD & MPC & MV & MUD & MLAT & MESD & MRT & MTT & MTR \\
\hline Nolz, Doerner, Gutjahr and Hartl (2010) & $\mathrm{X}$ & & & & & $\mathrm{X}$ & & $\mathrm{X}$ & & \\
\hline Rawls and Turnquist (2010) & $\mathrm{X}$ & & & & $\mathrm{X}$ & & & & & \\
\hline Nolz, Doerner and Hartl (2010) & $\mathrm{X}$ & $\mathrm{X}$ & & & $\mathrm{X}$ & & & & & \\
\hline Vitoriano, Ortuño, Tirado and Montero (2011) & $\mathrm{X}$ & & & & $\mathrm{X}$ & & $\mathrm{X}$ & & $\mathrm{X}$ & $\mathrm{X}$ \\
\hline Görmez, Köksalan and Salman (2011) & & $\mathrm{X}$ & & & & & & & & \\
\hline Gu (2011) & & & & & $\mathrm{X}$ & & & $\mathrm{X}$ & & \\
\hline Horner and Widener (2011) & $\mathrm{X}$ & & & & $\mathrm{X}$ & & & & & \\
\hline Lin, Batta, Rogerson, Blatt and Flanigan (2011) & $\mathrm{X}$ & & & & $\mathrm{X}$ & & $\mathrm{X}$ & & $\mathrm{X}$ & \\
\hline Zhan and Liu (2011) & & & & & $\mathrm{X}$ & & & & $\mathrm{X}$ & \\
\hline Clark and Culkin (2013) & $\mathrm{X}$ & & & $\mathrm{X}$ & $\mathrm{X}$ & & & & & $\mathrm{X}$ \\
\hline Huang, Smilowitz and Balcik (2012) & & & & & & & $\mathrm{X}$ & $\mathrm{X}$ & $\mathrm{X}$ & \\
\hline Abounacer, Renaud and Rekik (2012) & $\mathrm{X}$ & & & & $\mathrm{X}$ & & & & $\mathrm{X}$ & \\
\hline Berkoune, Renaud, Rekik and Ruiz (2012) & & & & & & & & & $\mathrm{X}$ & \\
\hline Bozorgi-Amiri, Jabalameli and Al-e-Hashem (2013) & $\mathrm{X}$ & & & & $\mathrm{X}$ & & & & $\mathrm{X}$ & \\
\hline Buzón (2012) & & & & & $\mathrm{X}$ & & $\mathrm{X}$ & $\mathrm{X}$ & $\mathrm{X}$ & \\
\hline Ben-Tal, Chung, Mandala and Yao (2011) & $\mathrm{X}$ & & & & & & & & & \\
\hline Naji-Azimi, Renaud, Ruiz and Salari (2012) & & $\mathrm{X}$ & & & & & & & & \\
\hline Noyan (2012) & & & & & & & & & & $\mathrm{X}$ \\
\hline Özdamar and Demir (2012) & & & & & & & & & $\mathrm{X}$ & \\
\hline Rottkemper, Fischer and Blecken (2012) & $\mathrm{X}$ & & & & $\mathrm{X}$ & & & & & \\
\hline Tricoire, Graf and Gutjahr (2012) & $\mathrm{X}$ & & & & $\mathrm{X}$ & & & & & \\
\hline Wohlgemuth, Oloruntoba and Clausen (2012) & & & & $\mathrm{X}$ & & & & & $\mathrm{X}$ & \\
\hline Zhang, Zhang, Zhang, Wei and Deng (2013) & & $\mathrm{X}$ & & & & & & & $\mathrm{X}$ & \\
\hline Anaya-Arenas, Ruiz and Renaud (2013) & $\mathrm{X}$ & & & & $\mathrm{X}$ & & $\mathrm{X}$ & & & \\
\hline Najafi, Eshghi and Dullaert (2013) & & & & $\mathrm{X}$ & $\mathrm{X}$ & & & & & \\
\hline Battini, Peretti, Persona and Sgarbossa (2014) & $\mathrm{X}$ & & & $\mathrm{X}$ & $\mathrm{X}$ & & & & $\mathrm{X}$ & \\
\hline Barzinpour and Esmaeili (2014) & $\mathrm{X}$ & & & & $\mathrm{X}$ & & & & & \\
\hline Rath and Gutjahr (2014) & $\mathrm{X}$ & & & & $\mathrm{X}$ & & & & & \\
\hline Rennemo, Rø, Hvattum and Tirado (2014) & $\mathrm{X}$ & & & & & & & $\mathrm{X}$ & & \\
\hline Edrissi, Nourinejad and Roorda (2015) & & $\mathrm{X}$ & & & $\mathrm{X}$ & & & $\mathrm{X}$ & & \\
\hline Hong, Jeong and Feng (2015) & $\mathrm{X}$ & & & & $\mathrm{X}$ & & & & & \\
\hline
\end{tabular}

MC: Min costs; MTD: minimize Traveled Distance; MPC: Minimize Path Complexity; MV: Minimize Vehicles; MUD: Min Unmet Demand; MLAT: Minimize Latest Arrival Time; MESD: Minimize Equity of Satisfied Demand; MRT: Minimize Response Time; MTT: Minimize Traveled Time; MTR: Minimize Travel Reliability.

Table 3. Main pursued performance criteria for a relief distribution problem

Based on Table 3, it can be observed that minimizing costs $(28.26 \%)$, unmet demand $(27.17 \%)$, travel time $(15.22 \%)$, and the response time $(13.04 \%)$ are all important. Although the risk and the equity of satisfying demand are not necessarily the most sought-after performance criteria in humanitarian logistics 
supply chains (5.43\% and $4.35 \%$, respectively), an increasing number of studies have begun to examine these areas in the last decade.

Once each stakeholder's profile, dimensions, and performance criteria are identified, their interests are prioritized by applying multi-criteria decision-making (MCDM) methods.

\subsection{Stakeholders Preference Prioritization (Stage 2)}

This stage defines and translates preferences from qualitative to quantitative values. To do so, a multi-criteria decision-making (MCDM) method is chosen. Here, we adopt the analytic hierarchy process (AHP) for its flexibility and ability to handle the imprecise judgment of experts in order to prioritize the stakeholders' preferences. This method assesses the relative importance of criteria and alternatives, and translates subjective judgments into relative weights of importance (Saaty, 1997). Nevertheless, a different MCDM method can be used according to the information availability.

\subsubsection{Problem Structure (AHP Method)}

The dimensions and performance criteria must be linked. To do so, the problem is hierarchized, which means the problem, its dimensions, and its performance criteria are linked and presented in a hierarchical structure.

In this case, the problem is identified in the first level of the hierarchy as one of reliable aid distribution. According to the given definitions, each identified performance criterion is linked to a dimension. In order to present these in a hierarchical structure, the dimensions occupy the second level and the performance criteria the third level, as shown in Figure 4.

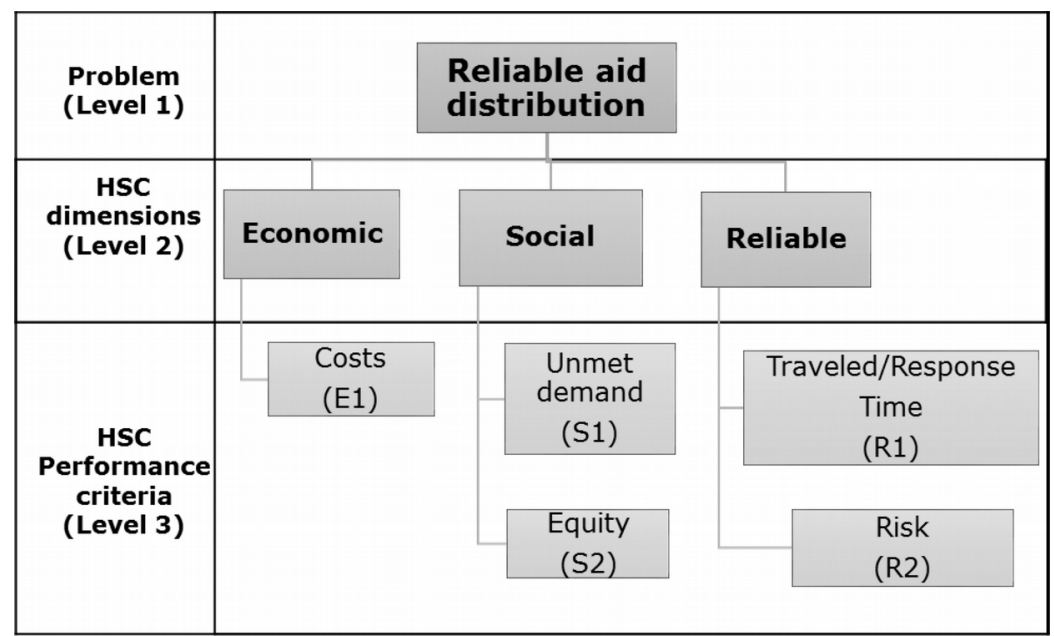

Figure 4. Reliable aid distribution problem structure 


\subsubsection{Pairwise Matrices}

Once the problem, dimensions, and performance criteria have been linked and presented in a hierarchical way, the pairwise matrices are developed.

To determine the importance each stakeholder assigns to a performance criterion, a literature review is performed, considering a query containing "coordination", "humanitarian logistics" and "performance criteria" as keywords to ISI Web and Scopus databases. As inclusion criteria, the literature review considered analytical publications such as peer-reviewed papers and conference proceedings with full-paper. The search was limited to the contributions within the Operational Research, Transportation, and Industrial Engineering categories and the data range was established between 1996 and 2016. The manuals and governmental or military reports were excluded from this research. Only written English contributions were considered. After this initial search, a total of 265 documents were found in the databases. A second filter helped us to eliminate duplicates and to ensure that the remaining papers integrate at least one of the stakeholders presented in Section 3.1. As the articles were reviewed the inclusion of other pertinent cited articles was carried out. Finally, a total of 21 papers met the inclusion and exclusion criteria (Table 4 and Table 7). In Table 4 the contributions are presented according to the stakeholder and Table 7 presents the contributions linking the performance criteria and each stakeholder. In Table 4, the contributions related to coordination are presented for the relationship between the performance criteria and the stakeholders.

Note that each stakeholder has a priority in humanitarian supply chain decisions. Thus, establishing the weight of each stakeholder is crucial. According to the AHP method, to determine the priority of each stakeholder over the humanitarian supply chain, an initial pairwise matrix must be developed (Table 6), as well as matrices to determine the stakeholders' preferences over each performance criterion (Tables 8-11).

\begin{tabular}{|c|c|c|c|}
\hline GOV & NGO & PS/D & $\mathbf{M}$ \\
\hline $\begin{array}{l}\text { Akhtar et al., } \\
\text { 2012; McLachlin } \\
\text { and Larson, 2011; } \\
\text { Balland, } 2013\end{array}$ & $\begin{array}{l}\text { Tatham and Kovacs, 2010; Tomasini } \\
\text { and Van Wassenhove, 2009; Cozzolino, } \\
\text { 2012; Heaslip, 2013; Heaslip and } \\
\text { Barber, 2014; Heaslip, 2012; } \\
\text { Hovhanessian, 2012; Kovács and } \\
\text { Spens, 2007; McLachlin and Larson, } \\
\text { 2011; Pettit, Beresford and Drive, 2007; } \\
\text { Balland, 2013; Dolinskaya et al., 2011; } \\
\text { Egan, 2010; Moshtari and Gonçalves, } \\
\text { 2011; Scholten, Scott and Fynes, 2010; } \\
\text { Schulz and Blecken, 2010; Tzeng et al., } \\
\text { 2007; Huang et al, } 2011\end{array}$ & $\begin{array}{l}\text { Balland, 2013; Cozzolino, 2012; } \\
\text { Egan, 2010; Heaslip, 2013; } \\
\text { Heaslip, 2012; Hovhanessian, } \\
\text { 2012; Huang et al, 2011; } \\
\text { Moshtari and Gonçalves, 2011; } \\
\text { Scholten et al., 2010; Tomasini } \\
\text { and Van Wassenhove, 2009; } \\
\text { Kovács and Spens, 2007; } \\
\text { McLachlin and Larson, } 2011\end{array}$ & $\begin{array}{l}\text { Barbarosglu et al., 2002; } \\
\text { Heaslip, 2013; Heaslip and } \\
\text { Barber, 2014; Heaslip, } \\
\text { 2012; Kovács and Spens, } \\
\text { 2007; McLachlin and } \\
\text { Larson, 2011; Pettit et al., } \\
2007\end{array}$ \\
\hline
\end{tabular}

Table 4. Contributions (stakeholders) 
From equation (1), five pairwise matrices are developed (Table 6, Tables 8-11). The relationship with no contributions for $\mathrm{i}$ or $\mathrm{j}$ will be considered as 9.00 or 0.11 , depending on whether zero lies in the denominator or numerator, respectively.

$$
R I(i, j)=\text { No. of references }(i) / \text { No. of references }(j)
$$

\begin{tabular}{|c|l|}
\hline Saaty's scale & \multicolumn{1}{|c|}{ Relative importance of the two sub-elements } \\
\hline 1 & Equally important \\
\hline 3 & Moderate importance of one over another \\
\hline 5 & Strongly important \\
\hline 7 & Very strongly important \\
\hline 9 & Extremely important \\
\hline & Table 5. Saaty's scale (Saaty, 1980) \\
\end{tabular}

Usually, the AHP method is applied using the Saaty's scale (Table 5). Nevertheless, due to the unavailability of real information, we generate the Tables 6-10 considering the number of contributions related to each concept (stakeholder or performance criteria). To develop the Table 6, we took into account the number of contributions that deal with each stakeholder, which in the case for the Government are 3 (Akhtar et al., 2012; McLachlin \& Larson, 2011; Balland, 2013) (see Table 4). The same procedure based on Table 4 is performed for the rest of Table 6 (for the NGO's are 18, for the Private Sector and Donors are 12, and for the Military are 7).

\begin{tabular}{|c|c|c|c|c|}
\hline \multicolumn{5}{|c|}{ Stakeholders } \\
\hline & GOV & NGO & PS $/$ D & M \\
\hline GOV & $1.00(3 / 3)$ & $0.17(3 / 18)$ & $0.25(3 / 12)$ & $0.43(3 / 7)$ \\
\hline NGO & $6.00(18 / 3)$ & $1.00(18 / 18)$ & $1.50(18 / 12)$ & $2.57(18 / 7)$ \\
\hline PS/D & $4.00(12 / 3)$ & $0.67(12 / 18)$ & $1.00(12 / 12)$ & $1.71(12 / 7)$ \\
\hline M & $2.33(7 / 3)$ & $0.39(7 / 18)$ & $0.58(7 / 12)$ & $1.00(7 / 7)$ \\
\hline
\end{tabular}

Table 6. Priorities among stakeholders

To develop the Tables 8-11, we considered the Table 7, which shows the number of contributions that linked the performance criteria with each stakeholder. To develop the Table 8 (Government), we considered the number of contributions that deal with each stakeholder, which in the case of E1 is 3 (Akhtar et al., 2012; McLachlin \& Larson, 2011) (see Table 7). The same procedure based on Table 7 is 
performed for the rest of Table 8 (for S1 is 0 , for S2 is 0 , for R1 is 2 and for R2 is 1). Table 7 and the same procedure are used to generate the Tables 9-11.

\begin{tabular}{|c|c|c|c|c|}
\hline Criteria & GOV & NGO & PS/D & $\mathbf{M}$ \\
\hline E1 & $\begin{array}{l}\text { Akhtar et al., 2012; } \\
\text { McLachlin and } \\
\text { Larson, } 2011\end{array}$ & $\begin{array}{l}\text { Tatham and Kovacs, 2010; } \\
\text { Tomasini and Van Wassenhove, } \\
2009\end{array}$ & $\begin{array}{l}\text { Balland, 2013; Cozzolino, } \\
\text { 2012; Egan, 2010; } \\
\text { Heaslip, 2013; Heaslip, } \\
\text { 2012; Hovhanessian, } \\
\text { 2012; Huang, Li and } \\
\text { Omitaomu, 2011; } \\
\text { Moshtari and Gonçalves, } \\
\text { 2011; Scholten, Scott and } \\
\text { Fynes, 2010; Tomasini } \\
\text { and Van Wassenhove, } \\
\text { 2009 }\end{array}$ & Barbarosolu et al., 2002 \\
\hline S1 & & $\begin{array}{l}\text { Cozzolino, 2012; Heaslip, 2013; } \\
\text { Heaslip and Barber, 2014; } \\
\text { Heaslip, 2012; Hovhanessian, } \\
\text { 2012; Kovács and Spens, 2007; } \\
\text { McLachlin and Larson, 2011; } \\
\text { Pettit, Beresford and Drive, } \\
2007\end{array}$ & (Balland, 2013) & Barbarosolu et al., 2002 \\
\hline S2 & & $\begin{array}{l}\text { Balland, 2013; Heaslip, 2013; } \\
\text { Heaslip, 2012; McLachlin and } \\
\text { Larson, } 2011\end{array}$ & & \\
\hline $\mathrm{R} 1$ & $\begin{array}{l}\text { Balland, 2013; } \\
\text { McLachlin and } \\
\text { Larson, } 2011\end{array}$ & $\begin{array}{l}\text { Balland, 2013; Cozzolino, 2012; } \\
\text { Dolinskaya et al., 2011; Egan, } \\
\text { 2010; Heaslip, 2013; } \\
\text { Hovhanessian, 2012; Kovács } \\
\text { and Spens, 2007; McLachlin and } \\
\text { Larson, 2011; Moshtari and } \\
\text { Gonçalves, 2011; Pettit et al., } \\
\text { 2007; Scholten et al., 2010; } \\
\text { Schulz and Blecken, 2010; } \\
\text { Tatham and Kovacs, 2010; } \\
\text { Tomasini and Van Wassenhove, } \\
\text { 2009; Tzeng et al., } 2007\end{array}$ & $\begin{array}{l}\text { Balland, 2013; Heaslip, } \\
\text { 2013; Kovács and Spens, } \\
\text { 2007; McLachlin and } \\
\text { Larson, 2011; Tomasini } \\
\text { and Van Wassenhove, } \\
2009\end{array}$ & \\
\hline $\mathrm{R} 2$ & (Balland, 2013) & $\begin{array}{l}\text { Balland, 2013; Huang et al., } \\
2011\end{array}$ & & $\begin{array}{l}\text { Barbarosolu et al., 2002; } \\
\text { Heaslip, 2013; Heaslip and } \\
\text { Barber, 2014; Heaslip, 2012; } \\
\text { Kovács and Spens, 2007; } \\
\text { McLachlin and Larson, } \\
\text { 2011; Pettit et al., 2007 }\end{array}$ \\
\hline
\end{tabular}

Table 7. Contributions (stakeholder vs performance criteria) 


\begin{tabular}{|c|c|c|c|c|c|}
\hline \multicolumn{6}{|c|}{ Government } \\
\hline & E1 & S1 & $\mathbf{S} 2$ & $\mathbf{R} 1$ & $\mathbf{R} 2$ \\
\hline E1 & $1.00(2 / 2)$ & $9.00(2 / 0)$ & $9.00(2 / 0)$ & $1.00(2 / 2)$ & $2.00(2 / 1)$ \\
\hline S1 & $0.11(0 / 2)$ & $1.00(0 / 0)$ & $1.00(0 / 0)$ & $0.11(0 / 2)$ & $0.11(0 / 1)$ \\
\hline S2 & $0.11(0 / 2)$ & $1.00(0 / 0)$ & $1.00(0 / 0)$ & $0.11(0 / 2)$ & $0.11(0 / 1)$ \\
\hline R1 & $1.00(2 / 2)$ & $9.00(2 / 0)$ & $9.00(2 / 0)$ & $1.00(2 / 2)$ & $2.00(2 / 1)$ \\
\hline $\mathrm{R} 2$ & $0.50(1 / 2)$ & $9.00(1 / 0)$ & $9.00(1 / 0)$ & $0.50(1 / 2)$ & $1.00(1 / 1)$ \\
\hline
\end{tabular}

Table 8. Government's performance criteria priorities

\begin{tabular}{|c|c|c|c|c|c|}
\hline & \multicolumn{6}{|c|}{ E1 } & S1 & S2 & R1 & R2 \\
\hline E1 & $1.00(4 / 4)$ & $2.00(4 / 2)$ & $1.33(4 / 3)$ & $4.00(4 / 1)$ & $1.00(4 / 4)$ \\
\hline S1 & $0.50(2 / 4)$ & $1.00(2 / 2)$ & $0.67(2 / 3)$ & $2.00(2 / 1)$ & $0.50(2 / 4)$ \\
\hline S2 & $0.75(3 / 4)$ & $1.50(3 / 2)$ & $1.00(3 / 3)$ & $3.00(3 / 1)$ & $0.75(3 / 4)$ \\
\hline R1 & $0.25(1 / 4)$ & $0.50(1 / 2)$ & $0.33(1 / 3)$ & $1.00(1 / 1)$ & $0.25(1 / 4)$ \\
\hline R2 & $1.00(4 / 4)$ & $2.00(4 / 2)$ & $1.33(4 / 3)$ & $4.00(4 / 1)$ & $1.00(4 / 4)$ \\
\hline
\end{tabular}

Table 9. NGO performance criteria priorities

\begin{tabular}{|c|c|c|c|c|c|}
\hline \multicolumn{7}{|c|}{ Private sector/Donors } \\
\hline & E1 & S1 & S2 & R1 & R2 \\
\hline E1 & $1.00(9 / 9)$ & $9.00(9 / 1)$ & $9.00(9 / 0)$ & $1.80(9 / 5)$ & $9.00(9 / 0)$ \\
\hline S1 & $0.11(1 / 9)$ & $1.00(1 / 1)$ & $9.00(1 / 0)$ & $0.20(1 / 5)$ & $9.00(1 / 0)$ \\
\hline S2 & $0.11(0 / 9)$ & $0.11(0 / 1)$ & $1.00(0 / 0)$ & $0.11(0 / 5)$ & $1.00(0 / 0)$ \\
\hline R1 & $0.56(5 / 9)$ & $5.00(5 / 1)$ & $9.00(5 / 0)$ & $1.00(5 / 5)$ & $9.00(5 / 0)$ \\
\hline R2 & $0.11(0 / 9)$ & $0.11(0 / 1)$ & $1.00(0 / 0)$ & $0.11(0 / 5)$ & $1.00(0 / 0)$ \\
\hline
\end{tabular}

Table 10. Private sector/donors' performance criteria priorities

\begin{tabular}{|c|c|c|c|c|c|}
\hline \multicolumn{2}{|c|}{ E1 } & S1 & S2 & R1 & R2 \\
\hline E1 & $1.00(1 / 1)$ & $1.00(1 / 1)$ & $9.00(1 / 0)$ & $9.00(1 / 0)$ & $0.14(1 / 7)$ \\
\hline S1 & $1.00(1 / 1)$ & $1.00(1 / 1)$ & $9.00(1 / 0)$ & $9.00(1 / 0)$ & $0.14(1 / 7)$ \\
\hline S2 & $0.11(0 / 1)$ & $0.11(0 / 1)$ & $1.00(0 / 0)$ & $1.00(0 / 0)$ & $0.11(0 / 7)$ \\
\hline R1 & $0.11(0 / 1)$ & $0.11(0 / 1)$ & $1.00(0 / 0)$ & $1.00(0 / 0)$ & $0.11(0 / 7)$ \\
\hline R2 & $7.00(7 / 1)$ & $7.00(7 / 1)$ & $9.00(7 / 0)$ & $9.00(7 / 0)$ & $1.00(7 / 7)$ \\
\hline
\end{tabular}

Table 11. Military's performance criteria priorities 
The five $R I(i, j)$ matrices represent the relationships among stakeholders (Table 6 ). Table 8 shows the performance criteria priorities of the government, and Table 9, Table 10, and Table 11 show the same information for NGOs, the private sector/donors, and the military, respectively.

\subsubsection{Stakeholders' Preference Priorities (weights)}

Finally, considering the pairwise matrices, the relative importance of each stakeholder in the humanitarian supply chain and their performance criteria priorities are shown Table 12 and Table 13, respectively. Then, the stakeholders' priorities are used to develop a final matrix (Table 14), which represents the interests of stakeholders based on the performance criteria established previously.

\begin{tabular}{|c|c|}
\hline Stakeholder & Stakeholder priority \\
\hline Government & $7.80 \%$ \\
\hline NGO & $46.79 \%$ \\
\hline Private Sector/Donors & $27.21 \%$ \\
\hline Military & $18.20 \%$ \\
\hline
\end{tabular}

Table 12. Stakeholders' priorities

\begin{tabular}{|c|c|c|c|c|c|}
\hline \multirow{2}{*}{ Stakeholder } & \multicolumn{5}{|c|}{ Performance criteria priorities } \\
\cline { 2 - 6 } & E1 & S1 & S2 & R1 & R2 \\
\hline Government & $34.92 \%$ & $3.37 \%$ & $3.37 \%$ & $34.92 \%$ & $23.43 \%$ \\
\hline NGO & $28.57 \%$ & $14.29 \%$ & $21.43 \%$ & $7.14 \%$ & $28.57 \%$ \\
\hline Private Sector/Donors & $49.30 \%$ & $13.55 \%$ & $2.86 \%$ & $31.43 \%$ & $2.86 \%$ \\
\hline Military & $16.58 \%$ & $16.58 \%$ & $2.87 \%$ & $2.87 \%$ & $61.10 \%$ \\
\hline
\end{tabular}

Table 13. Stakeholders' performance criteria priorities

Based on Table 13, we conclude that the priority for governmental organizations is the economic aspect, but without losing control of the response/travel time. Non-governmental organizations focus on the delivery of relief, according to a plan, but are also concerned about the economic aspect (turning limited inputs into outputs). Then, the private sector and donors look to minimize the economic aspect. Finally, military organizations prioritize the reliability aspect, which, in this case, means delivering the relief according to a plan. 


\begin{tabular}{|c|c|}
\hline Performance criteria & Criteria priority \\
\hline Costs (E1) & $32.53 \%$ \\
\hline Unmet demand (S1) & $13.65 \%$ \\
\hline Equity (S2) & $11.59 \%$ \\
\hline Response/travel time (R1) & $15.14 \%$ \\
\hline Risk (R2) & $27.09 \%$ \\
\hline
\end{tabular}

Table 14. Performance criteria priorities

\subsection{Multi-criteria function (Stage 3)}

The five performance indicators (economic, unmet demand, equity, response/travel time, and risk) are integrated into a single minimization objective function, the general form of which is given by an equation that considers the adjustment of the aspects to be minimized. Note that, in order to formulate a single objective function to be minimized, equity is translated into inequity (i.e., Max Equity is translated into Min Inequity):

$$
\operatorname{Min} \alpha^{*} \mathrm{E} 1+\beta^{*} \mathrm{~S} 1+\gamma^{*} \mathrm{~S} 2+\delta^{*} \mathrm{R} 1+\varepsilon^{*} \mathrm{R} 2
$$

where:

$\alpha$ : Economic (E) weight

$\beta$ : Unmet demand (S1) weight

$\gamma$ : Inequity (S2) weight

$\delta:$ Response/travel time (R1) weight

$\varepsilon$ : Risk (R2) weight

Where: $\alpha=0.3253 ; \beta=0.1365 ; \gamma=0.1159 ; \delta=0.1514$; and $\varepsilon=0.2709$.

$$
\operatorname{Min} \alpha+\beta+\gamma+\delta+\varepsilon=1
$$

Leading to:

$$
\text { Min } \quad 0.3253 * \mathrm{E} 1+0.1365 * \mathrm{~S} 1+0.1159 * \mathrm{~S} 2+0.1514 * \mathrm{R} 1+0.2709 * \mathrm{R} 2
$$




\section{Conclusions and Future Research Work}

Motivated by the lack of applied research and the increased level of interest in this area, this study proposes a methodology that defines a multi-criteria framework for the hierarchical coordination of humanitarian supply chains. Although several works have presented optimization models and performance metrics, they are a long way from offering an integrated approach. Based on a literature review, we identified five performance criteria, namely economic, unmet demand, equity, response/travel time, and risk, in order to measure a reliable relief distribution process. These criteria were then prioritized based on the extensive literature review of research related to coordination in humanitarian supply chains.

Furthermore, in developing the multi-criteria framework, we noted the following: (1) the close relationship between the economic aspect and the private sector/donors; (2) the preference of NGOs to maximize demand, in an equitable manner, and in the shortest time; and (3) the military's priority of minimizing risk during the relief distribution process.

Note that the priorities ( $\%$ contributions) identified in the literature related to the performance criteria differ from the priorities obtained here with regard to the stakeholders' preferences (Table 13). However, in both cases, the economic aspect remains the highest priority $(28.26 \%, 32.53 \%)$. Then, risk $(27.09 \%)$ is the second-most important in terms of the relationship with stakeholders, but in the literature, it appears in $5.43 \%$ of the contributions. In addition, unmet demand is ranked second in the literature $(27.17 \%)$, but is fourth after applying the AHP method (13.65\%). This reinforces the importance of this study, which establishes that quantifying stakeholders' interests in order for them to be integrated into humanitarian decision-making processes increases the reliability of subsequent decisions. Once the performance criteria are prioritized, their integration into an objective function is possible, enabling them to be integrated into a mathematical optimization decision support system.

Illustrating the applicability of the methodology to reliable aid distribution is left for future work. Furthermore, conducting a sensitivity analysis of the performance of the indicators under different scenarios is highly recommended. 


\section{References}

Abounacer, R., Renaud, J., \& Rekik, M. (2012). An Exact Solution Approach for Multi-Objective Location-Transportation Problem for Disaster Response. Computers \& Operations Research, 41, 83-93. https://doi.org/10.1016/j.cor.2013.08.001

Adivar, B., \& Mert, A. (2010). International disaster relief planning with fuzzy credibility. Furay Optimization and Decision Making, 9(4), 413-433. https://doi.org/10.1007/s10700-010-9088-8

Afshar, A., \& Haghani, A. (2009). Supply chain management in disaster response. Mid-Atlantic Universities Transportation Center. [online] University of Maryland: Department of Civil \& Environmental Engineering. http://www.mautc.psu.edu/docs/UMD-2008-01.pdf

Akhtar, P., Marr, N.E., \& Garnevsca, E.V. (2012). Coordination in humanitarian relief chains: chain coordinators. Journal of Humanitarian Logistics and Supply Chain Management, 2(1), 85-103. https://doi.org/10.1108/20426741211226019

Altay, N., \& Green, W.G. (2006). OR/MS research in disaster operations management. European Journal of Operational Research, 175(1), 475-493. https://doi.org/10.1016/j.ejor.2005.05.016

Anaya-Arenas, A.M., Ruiz, A., \& Renaud, J. (2013). Models for a fair relief distribution: A network design problem. Industrial Engineering and Systems Management (IESM). Proceedings of 2013 International Conference on. 1-8.

Ang, L., \& Hern, G. (2015). Retos de la logística bumanitaria postdesastre en México ante el cambio climátic. 433.

Balcik, B., \& Beamon, B.M. (2008). Facility location in bumanitarian relief. 5567, December. https://doi.org/10.1080/13675560701561789

Balcik, B., \& Beamon, B.M., Krejci, C.C., Muramatsu, K.M., \& Ramirez, M. (2010). Coordination in humanitarian relief chains: Practices, challenges, and opportunities. International Journal of Production Economics, 126(1), 22-34. https://doi.org/10.1016/j.ijpe.2009.09.008

Balcik, B., Beamon, B., \& Smilowitz, K. (2008). Last Mile Distribution in Humanitarian Relief. Journal of Intelligent Transportation Systems, 12(2), 51-63. https://doi.org/10.1080/15472450802023329

Balland, J. (2013). Humanitarian Relief Organizations and Its Relationship with Logistics Service Providers. Jönköping University. 
Barbarosoğlu, G., \& Arda, Y. (2004). A two-stage stochastic programming framework for transportation planning in disaster response. Journal of the Operational Research Society, 55(1), 43-53.

https://doi.org/10.1057/palgrave.jors.2601652

Barbarosolu, G., Özdamar, L., \& Çevik, A. (2002). An interactive approach for hierarchical analysis of helicopter logistics in disaster relief operations. European Journal of Operational Research, 140(1), 118-133. https://doi.org/10.1016/S0377-2217(01)00222-3

Barzinpour, F., \& Esmaeili, V. (2014). A multi-objective relief chain location distribution model for urban disaster management. International Journal of Advanced Manufacturing Technology, (70), 1291-1302. https://doi.org/10.1007/s00170-013-5379-x

Battini, D., Peretti, U., Persona, A., \& Sgarbossa, F. (2014). Application of humanitarian last mile distribution model. Journal of Humanitarian Logistics and Supply Chain Management, 4(1), 131-148. http://www.emeraldinsight.com/10.1108/JHLSCM-01-2013-0001 https://doi.org/10.1108/JHLSCM-01-2013-0001

Ben-Tal, A., Chung, B.D., Mandala, S.R., \& Yao, T. (2011). Robust optimization for emergency logistics planning: Risk mitigation in humanitarian relief supply chains. Transportation Research Part B: Methodological, 45(8), 1177-1189. https://doi.org/10.1016/j.trb.2010.09.002

Berkoune, D., Renaud, J., Rekik, M., \& Ruiz, A. (2012). Transportation in disaster response operations. Socio-Economic Planning Sciences, 46(1), 23-32. https://doi.org/10.1016/j.seps.2011.05.002

Bozorgi-Amiri, A., Jabalameli, M.S., \& Al-e-Hashem, S.M.J.M. (2013). A multi-objective robust stochastic programming model for disaster relief logistics under uncertainty. OR Spectrum, 35(4), 905-933. https://doi.org/10.1007/s00291-011-0268-x

Buzón, C.I.E. (2012). Distribución balanceada de ayuda bumanitaria resuelto con un algoritmo metaheurístico. PhD thesis. Tecnologico de Monterrey.

Campbell, A.M., \& Jones, P.C. (2011). Prepositioning supplies in preparation for disasters. European Journal of Operational Research, 209(2), 156-165. https://doi.org/10.1016/j.ejor.2010.08.029

Campbell, A.M., Vandenbussche, D., \& Hermann, W. (2008). Routing for Relief Efforts. Transportation Science, 127-145. https://doi.org/10.1287/trsc.1070.0209

Chern, C.C., Chen, Y.L., \& Kung, L.C. (2010). A heuristic relief transportation planning algorithm for emergency supply chain management. International Journal of Computer Mathematics, 87(7), 1638-1664. https://doi.org/10.1080/00207160802441256 
Clark, A., \& Culkin, B. (2013). A network transshipment model for planning humanitarian relief operations after a natural disaster. In Vitoriano, B., Montero, J., \& Ruan, D. (Eds.) Decision Aid Models for Disaster Management and Emergencies (Vol. 7). Atlantis Press. 233-257. http://eprints.uwe.ac.uk/17612/ https://doi.org/10.2991/978-94-91216-74-9_11

Cozzolino, A. (2012). Humanitarian Logistics: Cross-sector cooperation in disaster relief management. Springer. https://doi.org/10.1007/978-3-642-30186-5

De Angelis, V., Mecoli, M., Nikoi, C., \& Storchi, G. (2007). Multiperiod integrated routing and scheduling of World Food Programme cargo planes in Angola. Computers and Operations Research, 34(6 Spec. Iss.), 1601-1615. https://doi.org/10.1016/j.cor.2005.07.012

Dolinskaya, I.S., Shi, Z.E., \& Smilowitz, K.R. (2011). Decentralized Approaches to Logistics Coordination in Humanitarian Relief. Proceeding of the 2011 Industrial Engineering Research Conference.

Edrissi, A., Nourinejad, M., \& Roorda, M.J. (2015). Transportation network reliability in emergency response. Transportation Research Part E: Logistics and Transportation Review, 80, 56-73. http://linkinghub.elsevier.com/retrieve/pii/S1366554515001052 https://doi.org/10.1016/j.tre.2015.05.005

Egan, M.J. (2010). Private goods and services contracts: Increased emergency response capacity or increased vulnerability? International Journal of Production Economics, 126(1), 46-56.

https://doi.org/10.1016/j.jipe.2009.10.005

Görmez, N., Köksalan, M., \& Salman, F. (2011). Locating disaster response facilities in Istanbul. Journal of Operational Research Society, (62), 1239-1252. https://doi.org/10.1057/jors.2010.67

Gralla, E., Goentzel, J., \& Fine, C. (2014). Assessing Trade-offs among Multiple Objectives for Humanitarian Aid Delivery Using Expert Preferences. Production and Operations Management, 23(6), 978-989. https://doi.org/10.1111/poms.12110

Gu, Y. (2011). Research on Optimization of Relief Supplies Distribution Aimed to Minimize Disaster Losses. Journal of Computers, 6(3), 603-609. https://doi.org/10.4304/jcp.6.3.603-609

Haghani, A., \& Oh, S.C. (1996). Formulation and solution of a multi-commodity, multi-modal network flow model for disaster relief operations. Transportation Research Part A: Policy and Practice, 30(3), 231-250. https://doi.org/10.1016/0965-8564(95)00020-8

Heaslip, G. (2013). Services operations management and humanitarian logistics. Journal of Humanitarian Logistics and Supply Chain Management, 5(1), 35-60. https://doi.org/10.1108/20426741311328501 
Heaslip, G., \& Barber, E. (2014). Using the military in disaster relief: systemising challenges and opportunities. Journal of Humanitarian Logistics and Supply Chain Management, 4(1), 60-81. http://www.emeraldinsight.com/10.1108/JHLSCM-03-2013-0013 https://doi.org/10.1108/JHLSCM-03-2013-0013

Heaslip, G.E. (2012). The Logistical Challenges of Coordinating Military and Civilian Agencies in Humanitarian Operations. Irish Academy of Management Conference, 353(0), 1-31.

Hong, J.-D., Jeong, K.-Y., \& Feng, K. (2015). Emergency relief supply chain design and trade-off analysis. Journal of Humanitarian Logistics and Supply Chain Management, 5(2), 162-187. https://doi.org/10.1108/JHLSCM-05-2014-0019

Horner, M.W., \& Downs, J.A. (2010). Optimizing hurricane disaster relief goods distribution: Model development and application with respect to planning strategies. Disasters, 34(3), 821-844. https://doi.org/10.1111/j.1467-7717.2010.01171.x

Horner, M.W., \& Downs, J.A. (2007). Testing a Flexible Geographic Information System - Based Network Flow Model for Routing Hurricane Disaster Relief Goods. Transportation Research Record: Journal of the Transportation Research Board, 2022, 47-54. https://doi.org/10.3141/2022-06

Horner, M.W., \& Widener, M.J. (2011). The effects of transportation network failure on people's accessibility to hurricane disaster relief goods: A modeling approach and application to a Florida case study. Natural Hazards, 59, 1619-1634. https://doi.org/10.1007/s11069-011-9855-z

Hovhanessian, M. (2012). Coordination Barriers between Humanitarian Organizations and Commercial Agencies in times of Disaster. Jönköping International Business School.

Hsueh, C.F., Chen, H.K., \& Chou, H.W. (2008). Dynamic vehicle routing for relief logistics in natural disasters. Vebicle Routing Problem. 71-84. https://doi.org/10.5772/5641

Huang, M., Smilowitz, K., \& Balcik, B. (2012). Models for relief routing: Equity, efficiency, and efficacy. Transportation Research Part E: Logistics and Transportation Review, 48(1), 2-18.

https://doi.org/10.1016/j.tre.2011.05.004

Huang, Y., Li, X., \& Omitaomu, O. (2011). Conceptual Supernetwork Model for Coordination Mechanisms in Humanitarian Relief Chain. In Doolen, T., \& Van Aken, E. (Eds.). Proceedings of the 2011 Industrial Engineering Research Conference.

Jia, H., Ordoñez, F., \& Dessouky, M.M. (2007). Solution approaches for facility location of medical supplies for large-scale emergencies. Computers \& Industrial Engineering, 52(2), 257-276. 
Kabra, G., Ramesh, A., \& Arshinder, K. (2015). Identification and prioritization of coordination barriers in humanitarian supply chain management. International Journal of Disaster Risk Reduction, 13, 128-138. https://doi.org/10.1016/j.ijdrr.2015.01.011

Kovács, G., \& Spens, K.M. (2007). Humanitarian logistics in disaster relief operations. International Journal of Physical Distribution \& Logistics Management, 37(2), 99-114. https://doi.org/10.1108/09600030710734820

Lin, Y. (2009). A logistics model for delivery of critical items in a disaster relief operation: heuristic approaches $\dagger$.

Lin, Y.H., Batta, R., Rogerson, P.A., Blatt, A., \& Flanigan, M. (2011). A logistics model for emergency supply of critical items in the aftermath of a disaster. Socio-Economic Planning Sciences, 45(4), 132-145. https://doi.org/10.1016/j.seps.2011.04.003

McLachlin, R., \& Larson, P.D. (2011). Building humanitarian supply chain relationships: lessons from leading practitioners. Journal of Humanitarian Logistics and Supply Chain Mangement, 1(1), 32-49. https://doi.org/10.1108/20426741111122402

Mete, H.O., \& Zabinsky, Z.B. (2010). Stochastic optimization of medical supply location and distribution in disaster management. Intern. Journal of Production Economics, 126(1), 76-84. https://doi.org/10.1016/j.ijpe.2009.10.004

Moshtari, M., \& Gonçalves, P. (2011). Understanding the drivers and barriers of coordination among humanitarian organizations. POMS 23rd Annual Conference. Chicago, Illinois, USA.

Najafi, M., Eshghi, K., \& Dullaert, W. (2013). A multi-objective robust optimization model for logistics planning in the earthquake response phase. Transportation Research Part E, 49(1), 217-249. https://doi.org/10.1016/j.tre.2012.09.001

Naji-Azimi, Z., Renaud, J., Ruiz, A., \& Salari, M. (2012). A covering tour approach to the location of satellite distribution centers to supply humanitarian aid. European Journal of Operational Research, 222(3), 596-605. https://doi.org/10.1016/j.ejor.2012.05.001

Nolz, P.C., Doerner, K.F., Gutjahr, W.J., \& Hartl, R.F. (2010). A Bi-objective metaheuristic for disaster relief operation planning. Studies in Computational Intelligence, 272, 167-187. https://doi.org/10.1007/978-3-64211218-8_8

Nolz, P.C., Doerner, K.F., \& Hartl, R.F. (2010). Water distribution in disaster relief. International Journal of Physical Distribution \& Logistics Management, 40(8/9), 693-708. https://doi.org/10.1108/09600031011079337 
Noyan, N. (2012). Risk-averse two-stage stochastic programming with an application to disaster management. Computers \& Operations Research. 39(3), 541-559. https://doi.org/10.1016/j.cor.2011.03.017

Oh, S.C., \& Haghani, A. (1997). Testing and evaluation of a multi-commodity multi-modal network flow model for disaster relief management. Journal of Advanced Transportation, 31(3), 249-282. https://doi.org/10.1002/atr.5670310304

Ortuño, M.T., Cristóbal, P., Ferrer, J.M., Martín-Campo, F.., Muñoz, S., Tirado, G. et al. (2013). Decision Aid Models and Systems for Humanitarian Logistics. A Survey. In Vitoriano, B., Montero, J., \& Ruan, D. (Eds.) Decision Aid Models for Disaster Management and Emergencies (Vol. 7). Spain: Atlantis Press. https://doi.org/10.2991/978-94-91216-74-9_2

Özdamar, L., Ekinci, E., \& Küçükyazici, B (2004). Emergency Logistics Planning in Natural Disasters. Annals of Operations Research, 129(1-4), 217-245. https://doi.org/10.1023/B:ANOR.0000030690.27939.39

Özdamar, L., \& Demir, O. (2012). A hierarchical clustering and routing procedure for large scale disaster relief logistics planning. Transportation Research Part E: Logistics and Transportation Review, 48(3), 591-602. http://www.sciencedirect.com/science/article/pii/S1366554511001396/pdfft? $\underline{\mathrm{md} 5=\mathrm{fb} 14 \mathrm{cc} 103 \mathrm{ee} 03 \mathrm{ed} 39628 \mathrm{a} 8 \mathrm{~d} 0 \mathrm{f} 025 \mathrm{c} 0 \mathrm{fc} \& \mathrm{pid}=1 \text {-s2.0-S1366554511001396-main.pdf }}$ https://doi.org/10.1016/j.tre.2011.11.003

Pettit, S.J., Beresford, A.K.C., \& Drive, C. (2007). Emergency relief logistics: an evaluation of military, non-military and composite response models. International Journal of Logistics Research and Applications: A Leading Journal of Supply Chain Management, 8(4), 313-331. https://doi.org/10.1080/13675560500407325

Rath, S., \& Gutjahr, W.J. (2014). A math-heuristic for the warehouse location-routing problem in disaster relief. Computers and Operations Research, 42, 25-39. https://doi.org/10.1016/j.cor.2011.07.016

Rawls, C.G., \& Turnquist, M.A. (2010). Pre-positioning of emergency supplies for disaster response. Transportation Research Part B, (44), 521-534. https://doi.org/10.1016/j.trb.2009.08.003

Rennemo, S.J., Rø, K.F., Hvattum, L.M., \& Tirado, G. (2014). A three-stage stochastic facility routing model for disaster response planning. Transportation Research Part E: Logistics and Transportation Review, 62, 116-135. http://www.sciencedirect.com/science/article/pii/S1366554513002007/pdfft? $\underline{\mathrm{md} 5=\mathrm{c} 78 \mathrm{a} 332 \mathrm{ce} 6 \mathrm{c} 8889 \mathrm{eb} 284915 \mathrm{f} 4422 \mathrm{c} 602 \mathrm{\alpha pid}=1-\mathrm{s} 2.0-\mathrm{S} 1366554513002007 \text {-main.pdf }}$ https://doi.org/10.1016/j.tre.2013.12.006

Rottkemper, B., Fischer, K., \& Blecken, A. (2012). A transshipment model for distribution and inventory relocation under uncertainty in humanitarian operations. Socio-Economic Planning Sciences, (46), 98-109. https://doi.org/10.1016/j.seps.2011.09.003

Saaty, T.L. (1980). The analytic bierarchy process. McGraw-Hill. 
Scholten, K., Scott, P.S., \& Fynes, B. (2010). (Le) agility in humanitarian aid (NGO) supply chains. International Journal of Physical Distribution Management, 40(8/9), 623-635.

https://doi.org/10.1108/09600031011079292

Schulz, S.F., \& Blecken, A. (2010). Horizontal cooperation in disaster relief logistics: benefits and impediments. International Journal of Physical Distribution \& Logistics Management, 40(8/9), 636-656. https://doi.org/10.1108/09600031011079300

Sheu, J.B. (2007). An emergency logistics distribution approach for quick response to urgent relief demand in disasters. Transportation Research Part E: Logistics and Transportation Review, 43(6), 687-709. https://doi.org/10.1016/j.tre.2006.04.004

Tatham, P., \& Kovacs, G. (2010). The application of "swift trust" to humanitarian logistics. International Journal of Production Economics, 126(1), 35-45. https://doi.org/10.1016/j.ijpe.2009.10.006

Tomasini, R.M., \& Van Wassenhove, L.N. (2009). From preparedness to partnerships: case study research on humanitarian logistics. International Transactions in Operational Research, 16(5), 549-559.

https://doi.org/10.1111/j.1475-3995.2009.00697.x

Tricoire, F., Graf, A., \& Gutjahr, W.J. (2012). The bi-objective stochastic covering tour problem. Computers \& Operations Research, 39(7), 1582-1592. http://linkinghub.elsevier.com/retrieve/pii/S030505481100270X https://doi.org/10.1016/j.cor.2011.09.009

Tzeng, G.-H., Cheng, H.-J., \& Huang, T.D. (2007). Multi-objective optimal planning for designing relief delivery systems. Transportation Research Part E: Logistics and Transportation Review, 43(6), 673-686. https://doi.org/10.1016/j.tre.2006.10.012

Viswanath, K., \& Peeta, S. (2003). Multicommodity Maximal Covering Network Design Problem for Planning Critical Routes for Earthquake Response. Transportation Research Record. https://doi.org/10.3141/1857-01

Vitoriano, B., Ortuño, M.T., \& Tirado, G. (2009). HADS, a Goal Programming-Based Humanitarian Aid Distribution System. Journal of Multi-Criteria Decision Analysis, (16), 55-64. https://doi.org/10.1002/mcda.439

Vitoriano, B., Ortuño, M.T., Tirado, G., \& Montero, J. (2011). A multi-criteria optimization model for humanitarian aid distribution. Journal of Global Optimization, 51(2), 189-208. https://doi.org/10.1007/s10898010-9603-z

Wohlgemuth, S., Oloruntoba, R., \& Clausen, U. (2012). Dynamic vehicle routing with anticipation in disaster relief. Socio-Economic Planning Sciences, (46), 261-271. https://doi.org/10.1016/j.seps.2012.06.001 
Yi, W., \& Kumar, A. (2007). Ant colony optimization for disaster relief operations. Transportation Research Part E: Logistics and Transportation Review, 43(6), 660-672. https://doi.org/10.1016/j.tre.2006.05.004

Yi, W., \& Özdamar, L. (2007). A dynamic logistics coordination model for evacuation and support in disaster response activities. European Journal of Operational Research, 179(3), 1177-1193. https://doi.org/10.1016/j.ejor.2005.03.077

Yuan, Y., \& Wang, D. (2009). Path selection model and algorithm for emergency logistics management. Computers \& Industrial Engineering, 56(3), 1081-1094. https://doi.org/10.1016/j.cie.2008.09.033

Zhan, S.L., \& Liu, N. (2011). A multi-objective stochastic programming model for emergency logistics based on goal programming. Proceedings - 4th International Joint Conference on Computational Sciences and Optimization, CSO 2011. 640-644. https://doi.org/10.1109/CSO.2011.44

Zhang, X., Zhang, Z., Zhang, Y., Wei, D., \& Deng, Y. (2013). Route selection for emergency logistics management: A bio-inspired algorithm. Safety Science, 54, 87-91. https://doi.org/10.1016/j.ssci.2012.12.003

Zhu, C., \& Ji, G. (2009). Emergency logistics and the distribution model for quick response to urgent relief demand. Proceedings of the 2009 6th International Conference on Service Systems and Service Management, ICSSSM '09. 368-374.

Zografos, K.G., \& Androutsopoulos, K.N. (2005). A decision support system for hazardous materials transportation and emergency response management. 84th Annual Meeting of the Transportation Research Board. Washington, D.C.

Journal of Industrial Engineering and Management, 2017 (www.jiem.org)

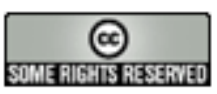

Article's contents are provided on an Attribution-Non Commercial 3.0 Creative commons license. Readers are allowed to copy, distribute and communicate article's contents, provided the author's and Journal of Industrial Engineering and Management's names are included. It must not be used for commercial purposes. To see the complete license contents, please visit http://creativecommons.org/licenses/by-nc/3.0/. 